\title{
PENGARUH LAMA BLANCHING TERHADAP KARAKTERISTIK FISIKO-KIMIA DAN SENSORIK JUS KECAMBAH KEDELAI DAN WORTEL
}

\author{
Inda Riana Wulansari \\ Mazarina Devi \\ Laili Hidayati
}

\begin{abstract}
Abstrak: Tujuan penelitian ini menganalisis pengaruh lama blanching terhadap kadar $\beta$-karoten, vitamin E kapasitas antioksidan, viskositas, rentang warna, tingkat kesukaan panelis terhadap rasa, warna dan aroma jus. Penelitian ini menggunakan rancangan acak lengkap. Pengumpulan data fisiko kimia jus dilakukan dengan metode spektrofotometri sedangkan tingkat kesukaan dilakukan dengan uji organoleptik oleh 70 panelis. Analisis data pada penelitian ini menggunakan uji statistik Anava satu jalur. Hasil penelitian menunjukkan lama blanching memberikan pengaruh yang signifikan terhadap karaketristik fisiko-kimia dan tingkat kesukaan jus. Kadar $\beta$-karoten tertinggi, kadar Vitamin E dan kapasitas antioksidan tertinggi dimiliki oleh jus tanpa perlakuan blanching. Viskositas tertinggi dimiliki oleh jus dengan lama blanching 10 menit dan peningkatan waktu blanching memudarkan warna jingga jus kearah kuning. Tingkat kesukaan panelis terhadap aroma, rasa dan warna tertinggi pada perlakuan lama blanching 10 menit. Perlakuan tanpa blanching memiliki karakter fisiko-kimia yang paling baik.
\end{abstract}

Kata-kata Kunci: lama blanching, jus, kecambah kedelai, wortel

Abstract: The Effect of Blanching Time on Physico-Chemical Characteristics and Sensoric of Juice Made of Soybean and Carrot. The study aimed to analyze the effects of blanching time on $\beta$-carotene levels, vitamin $E$ antioxidant capacity, viscosity, color range, panelist preference level on taste, color and aroma of juice. This study used a complete randomized design. The physico-chemical characteristics data was collected by spectrophotometric method, while the level of preference was performed by organoleptic test by 70 panelists. Data analysis in this study used one way Anava test. The results showed that blanching time had a significant effect on physico-chemical characteristics and preference level of juice. The highest levels of $\beta$-carotene, Vitamin E levels and the highest antioxidant capacity were obtained by the juice without blanching treatment. The highest viscosity were obtained by juice with a 10 minute blanching and increased blanching time fades orange juice towards yellow. The highest panelist's preference level on aroma, taste and color was obtained on the 10 minute blanching treatment. The best physico-chemical character occurred on juice without blanching treatment.

Keywords: blanching time, juice, soy sprouts, carrots 
Organisasi Pangan dan Pertanian Dunia (FAO), konsumsi sayur dan buah negara kita hanya sebesar $35,30 \mathrm{~kg} / \mathrm{kapita} / \mathrm{tahun}$ di tahun 2005, kemudian tahun 2006 sebesar $34,06 \mathrm{~kg} / \mathrm{kapita} / \mathrm{tahun}$, dan tahun 2007 meningkat sebesar 40,90 kg/kapita/ tahun. Standar konsumsi buah dan sayur yang direkomendasikan FAO sebesar 73 $\mathrm{kg} / \mathrm{kapita} / \mathrm{tahun}$, sedangkan standar kecukupan untuk sehat 91,25 sebesar kg/kapita/tahun (Kuntarsih, 2010).

Jabaran data sebelumnya menunjukkan bahwa mayoritas orang Indonesia memprioritaskan konsumsi pada jenis pangan sumber energi. Hal ini tidak sejalan denga harapan perilaku makan sehat yang diharapkan. Perilaku makan sehat merupakan perilaku mengkonsumsi beberapa variasi kelompok makanan yang direkomendasikan yaitu karbohidrat, buah dan sayur, protein dan lemak, berlaku secara universal (Ogden dalam Dewi, 2013).

Tingginya konsumsi makronutrien tanpa diimbangi dengan konsumsi mikronutrien akan menyebabkan gangguan metabolisme dalam tubuh, kegemukan hingga meningkatkan faktor resiko dari beberapa penyakit degeneratif seperti, diabetes mellitus, jantung koroner dan stroke. Gaya hidup dan kebiasaan makan yang salah meningkatkan angka kegemukan masyarakat Indonesia. Data Riskesdas 2013 menunjukkan prevalensi obesitas perempuan dewasa (>18 tahun) 32,90\%, naik 18,10\% dari tahun 2007 (13,90\%) dan $17,50 \%$ dari tahun $2010(15,50 \%)$ dan prevalensi penduduk laki-laki dewasa obesitas pada tahun 2013 sebanyak $19,70 \%$, lebih tinggi dari tahun 2007 $(13,90 \%)$ dan tahun $2010(7,80 \%)$.

Selain berdampak pada kegemukan, menurut Silalahi (2006), ketidak seimbangan ini akan membentuk senyawa radikal bebas dan reaksi oksidasi pada tubuh manusia yang akan berlangsung seumur hidup. Tubuh memiliki alat pertahanan (antioksidan) sendiri yaitu, asam alpha lipoic, coenzyme Q10 dan gluta- thione (Joseph, dkk. 2008), namun dengan perkembangan industri yang pesat manusia berkontak langsung dengan berbagai sumber radikal bebas yang berasal dari lingkungan dan aktifitas fisik berlebih. Sistem pertahanan antioksidan kurang cukup memadai, maka untuk memenuhi kebutuhan antioksidan, diperlukan konsumsi makanan sumber antioksidan (Silalahi, 2006).

Wortel merupakan salah satu sayuran sumber $\beta$-karoten (Astawan dan Kasih 2008). Wortel yang melalui proses pemanasan akan meningkatkan daya serap antioksidan di dalam tubuh hingga sepertiganya (Astawan dan Kasih, 2008). Selanjutnya Wijayakusuma (2004) menyatakan bahwa dalam pemanfaatan wortel sebagai terapi pengobahan, hal yang perlu diperhatikan apabila pemakaian wortel dengan cara direbus, maka perebusannya hingga setengah matang.

Kedelai merupakan sayuran yang kaya akan antioksidan tetapi juga mengandung zat antigizi. Menurut (Winarsih, 2010), perkecambahan memberikan keuntungan antara lain dapat meningkatkan kadar beberapa jenis vitamin. Astawan dan Kasih (2008) menambahkan selama perkecambahan, kadar vitamin B meningkat 2,5 - 3 kali lipat. Demikian juga dengan vitamin E. Vitamin E mengalami peningkatan dari $24-230$ mg/100 g biji kering kedelai menjadi 17 - $662 \mathrm{mg} / 100 \mathrm{~g}$ kecambah, sedangkan vitamin $\mathrm{C}$ kecambah kedelai mengalami peningkatan dari jumlah sangat sedikit menjadi $12 \mathrm{mg}$ per $100 \mathrm{~g}$ yang dikecambahkan selama 48 jam.

Wortel dan kecambah kedelai sering dikonsumsi sebagai sayuran. Salah satu cara lain mengambil manfaat dari wortel dan kecambah kedelai adalah dengan mengolahnya menjadi jus. Wortel dan kecambah kedelai adalah bahan pangan dengan rasa dan aroma langu yang khas sehingga diperlukan pengolahan pendahuluan sebelum dijus untuk mengu- 
rangi bau langu pada saat dikonsumsi. Teknik blanching atau pemanasan pendahuluan pada bahan makanan dapat memperbaiki kualitas sensoris suatu produk.

Tujuan dilakukan blansir adalah untuk melemaskan produk, menginaktifkan enzim-enzim alami yang terdapat dalam bahan pangan yang akan dikaleng atau dibekukan, memusnahkan mikroba, menghilangkan udara yang terdapat dalam bahan dan memperbaiki warna (Wijayakusuma, 2007) serta mampu menghilangkan bau dan flavor yang tidak dikehendaki hingga mampu menghilangkan lendir pada beberapa jenis sayur-sayuran (Hawusiwa, 2010). Selain itu teknik pemanasan pada wortel dapat meningkatkan kapasitas antioksidan dalam bahan tersebut. Berdasarkan penelitian yang dilakukan Aisyah, dkk. (2014), dihasilkan bahwa baktivitas antioksidan wortel yang direbus pada $95^{\circ} \mathrm{C}$ meningkat $16,82 \%$ dibandingkan ketika dalam keadaan mentahnya. Kusdibyo dan $\mathrm{Mu}-$ sadad dalam Asgar (2006), menambahkan bahwa perlakuan waktu blanching dengan media air pada suhu $80-90{ }^{\circ} \mathrm{C}$ meningkatkan kecerahaan warna, nutrisi, dan tekstur wortel.

Jus merupakan bentuk praktis dalam mengkonsumsi sayur. Konsumsi jus minimal dua gelas hingga delapan gelas dalam sehari (Lim dan Yip, 2004). Selain segar saat diminum, jus buah dan sayuran juga memberi nilai gizi lebih, memenuhi kebutuhan vitamin dan mineral dalam waktu lebih cepat dan penyerapannya lebih cepat. Buah yang dijus akan diabsorbsi sistem pencernaan dalam waktu 20 menit sedangkan buah yang tidak dalam bentuk jus membutuhkan waktu 18 jam untuk di absorbsi sistem pencernaan (Heltty, 2008).

Berdasarkan data yang telah dikemukakan akan dilakukan penelitian tentang pengaruh lama blanching terhadap karakteristik fisiko-kimia dan sensorik jus (kecambah kedelai dan wortel). Pene- litian ini diharapkan dapat memperbaiki karakter fisiko-kimia dan sensorik jus.

\section{METODE}

Penelitian yang dilakukan merupakan penelitian eksperimen. Rancangan penelitian menggunakan rancangan acak lengkap (RAL). Perlakuan dalam penelitian ini adalah lama waktu blanching pada jus kecambah kedelai dan wortel yaitu $\mathrm{P} 1=$ kontrol, $\mathrm{P} 2=5$ menit, $\mathrm{P} 3=10$ menit. Analisis sifat kimia yang dilakukan adalah kadar $\beta$-karoten, kadar vitamin $\mathrm{E}$ dan aktivitas antioksidan terhadap jus kecambah kedelai wortel yang dibuat dengan 3 perlakuan. Uji kandungan kimia dengan menggunakan spektrofotometri

Uji fisik dalam penelitian ini meliputi uji viskositas dan uji warna dilakukan di laboratorium Kimia Universitas Muhammadiyah Malang. Metode yang digunakan adalah viskometri dan kolormetri.

Uji hedonik pada penelitian ini meliputi uji hedonik terhadap warna, rasa, dan aroma. Jus sebagai bahan sampel dalam uji hedonik adalah jus yang telah diberi kode acak. Uji hedonik dilakukan dengan 2 kali pengulangan.

Mekanisme pelaksanaan uji hedonik yang telah dilakukan dapat dijelaskan sebagai berikut: (1) Memberikan penjelasan tentang maksud dan tujuan penelitian dan prosedur penelitian secara umum; (2) Panelis diberi penejelasan ulang tentang prosedur uji hedonik dan cara pengisian angket; (3) Pelaksanaan uji hedonic dilakukan se-cara bergiliran (per 5 orang) di Labora- torium Produksi Jurusan Teknologi Industri Universitas Malang; dan (4) Panelis akan dihadapkan pada 4 gelas jus dengan kode masing-masing, air mineral sebagai penetralisir rasa, kopi sebagai penetralisir aroma, format penilaian uji hedonik dan pulpen. 
Data yang diperoleh dianalisis dengan sidik ragam, apabila ada pengaruh perlakuan yang signifikan terhadap variable yang diamati, maka analisi dilanjutkan dengan uji Duncan.

Bahan baku yang digunakan dalam pembuatan jus adalah wortel lokal dan kecambah kedelai dengan waktu kecambah 48 jam. Alat yang digunakan dalam pembuatan jus meliputi: timbangan, pisau, talenan, blender, sendok, panci, kompor thermometer, timer, spektrofotometer, viscometer, dan color reader. Pengamatan yang dilakukan pada jus meliputi kadar $\beta$-karoten (metode spektrofotometri), vitamin $\mathrm{E}$ (metode spektrofotometri), kapasitas antioksidan (metode spektrofotometri), viskositas (viskometri), uji warna (kolormetri) dan uji sensorik (uji kesukaan pada 70 panelis).

Pelaksanaan penelitian dilakukan dalam 2 tahapan.Tahap pertama adalah mengecambahkan biji kedelai terlebih dahulu kemudian tahap kedua adalah pembuatan jus kecambah kedelai dan wortel.

\section{HASIL}

Kadar $\beta$-karoten jus kecambah kedelai dan wortel yang diperoleh sebesar 9,97- 13,44 mg. Hasil data rerata kadar $\beta$ karoten dapat dilihat pada Tabel 1.

Kadar $\beta$-karoten menunujukkan perbedaan yang nyata antara perlakuan. Jus kecambah kedelai dan wortel tanpa

Tabel 1. Rerata Kadar $\beta$-karoten jus Kecambah Kedelai dan Wortel

\begin{tabular}{cccc}
\hline Sampel & Ulangan & $\begin{array}{c}\boldsymbol{\beta} \text {-karoten } \\
(\mathbf{m g})\end{array}$ & $\begin{array}{c}\text { Rerata } \\
(\mathbf{m g})\end{array}$ \\
\hline P1 & 1 & 13,4895 & $13,449 \mathrm{a}$ \\
& 2 & 13,4082 & \\
P2 & 1 & 11,7025 & $11,756 \mathrm{~b}$ \\
& 2 & 11,8094 & \\
P3 & 1 & 9,9884 & $9,976 \mathrm{c}$ \\
& 2 & 9,9648 & \\
\hline
\end{tabular}

Keterangan: huruf yang sama di belakang angka pada kolom yang sama menunjukkan tidak berbeda nyata $(\mathrm{p}>0.05)$ blanching berbeda dengan jus kecambah kedelai dan wortel dengan blanching 5 menit. Jus kecambah kedelai dan wortel tanpa blanching berbeda dengan jus kecambah kedelai dan wortel dengan blanching 10 menit. Jus kecambah kedelai dan wortel dengan blanching 5 menit berbeda dengan jus kecambah kedelai dan wortel dengan blanching 10 menit.

Kadar vitamin E jus kecambah kedelai dan wortel yang diperoleh sebesar 0,61-1,07 mg Hasil data rerata kadar vitamin E dapat dilihat pada Tabel 2.

Tabel 2. Rerata Kadar Vitamin E Jus Kecambah Kedelai dan Wortel

\begin{tabular}{cccc}
\hline Sampel Ulangan & $\begin{array}{c}\boldsymbol{\beta} \text {-karoten } \\
\text { (mg) }\end{array}$ & $\begin{array}{c}\text { Rerata } \\
\text { (mg) }\end{array}$ \\
\hline P1 & 1 & 1,067 & $1,0755 \mathrm{a}$ \\
& 2 & 1,084 & \\
P2 & 1 & 0,913 & $0,921 \mathrm{~b}$ \\
& 2 & 0,929 & \\
P3 & 1 & 0,621 & $90,617 \mathrm{c}$ \\
& 2 & 0,613 & \\
\hline
\end{tabular}

Keterangan: huruf yang sama di belakang angka pada kolom yang sama menunjukkan tidak berbeda nyata $(\mathrm{p}>0.05)$

Tabel 3. Rerata Kapasitas Antioksidan Jus Kecambah Kedelai dan Wortel

\begin{tabular}{cccc}
\hline Sampel & Ulangan & $\begin{array}{c}\text { Kapasitas } \\
\text { Antioksidan } \\
(\boldsymbol{\%})\end{array}$ & $\begin{array}{c}\text { Rerata } \\
(\boldsymbol{\%})\end{array}$ \\
\hline P1 & 1 & 28,922 & $29,3005 \mathrm{a}$ \\
& 2 & 29,679 & \\
P2 & 1 & 22,684 & $23,1565 \mathrm{~b}$ \\
& 2 & 23,629 & \\
P3 & 1 & 16,257 & $15,8835 \mathrm{c}$ \\
& 2 & 15,501 & \\
\hline
\end{tabular}

Keterangan: huruf yang sama di belakang angka pada kolom yang sama menunjukkan tidak berbeda nyata $(\mathrm{p}>0.05)$

Kadar vitamin E menunujukkan perbedaan yang nyata antara perlakuan. Jus kecambah kedelai dan wortel tanpa blanching berbeda denganjus kecambah kedelai dan wortel dengan blanching 5 menit. Jus kecambah kedelai dan wortel tanpa blanching berbeda dengan jus kecambah kedelai dan wortel dengan 
blanching 10 menit. Selanjutnya, jus kecambah kedelai dan wortel dengan blanching 5 menit berbeda dengan jus kecambah kedelai dan wortel dengan blanching 10 menit.

Kapasitas antioksidan jus kecambah kedelai dan wortel yang diperoleh berdasarkan nilai IC50 sebesar 194,630215,125 Hasil data rerata kapasitas antioksidan dapat dilihat pada Tabel 3.

Kapasitastas antioksidan jus kecambah kedelai dan wortel tanpa blanching berbeda dengan jus kecambah kedelai dan wortel dengan perlakuan blanching 5 menit serta 10 menit. Selanjutnya, jus kecambah kedelai dan wortel dengan blanching 5 menit berbeda dengan jus kecambah kedelai dan wortel dengan blanching 10 menit.

Pengukuran dengan standar IC50 pada Tabel 4 menunjukkan nilai formula 1 adalah 194,630, nilai formula 2 adalah 210,091 dan nilai formula 3 adalah 215,125 .

$\begin{aligned} & \text { Tabel 4. Nilai IC50 Jus Kecambah } \\
& \text { Kedelai dan Wortel }\end{aligned}$
\begin{tabular}{ccc}
\hline Sampel & Ulangan & IC50 \\
\hline P1 & 1 & 194,630 \\
P2 & 2 & 210,091 \\
P3 & 1 & 215,125 \\
\hline
\end{tabular}

Data rerata dari aktivitas antioksidan jus kecambah kedelai dan wortel. Kapasitas antioksidan jus kecambah kedelai dan wortel tanpa blanching berbeda dengan jus kecambah kedelai dan wortel dengan blanching 5 menit dan juga dengan blanching 10 menit. Selanjutnya, jus kecambah kedelai dan wortel dengan blanching 5 menit berbeda dengan jus kecambah kedelai dan wortel dengan blanching 10 menit.

Uji viskositas jus kecambah kedelai dan wortel yang diperoleh sebesar 17,355-19,71. Sifat viskositas blanching 5 menit adalah $18,675 \mathrm{cps}$. Rerata sifat viskositas blanching 10 menit adalah
19,71 cps. Hasil data rerata uji viskositas dapat dilihat pada Tabel 5.

Sifat viskositas jus kecambah kedelai dan wortel tanpa blanching berbeda

Tabel 5. Rerata Uji Viskositas Jus Kecambah Kedelai dan Wortel

\begin{tabular}{cccc}
\hline Sampel & Ulangan & $\begin{array}{c}\text { Viskositas } \\
(\mathbf{c p})\end{array}$ & $\begin{array}{c}\text { Rerata } \\
(\mathbf{\%})\end{array}$ \\
\hline P1 & 1 & 17,29 & $17,355 \mathrm{a}$ \\
& 2 & 17,42 & \\
P2 & 1 & 18,63 & $18,675 \mathrm{~b}$ \\
& 2 & 18,72 & \\
P3 & 1 & 19,69 & $19,71 \mathrm{c}$ \\
& 2 & 19,73 & \\
\hline
\end{tabular}

Keterangan: huruf yang sama di belakang angka pada kolom yang sama menunjukkan tidak berbeda nyata $(\mathrm{p}>0.05)$

Tabel 6. Rerata Rentang Warna Merah Jus Kecambah Kedelai dan Wortel

\begin{tabular}{cccc}
\hline Sampel & Ulangan & $\begin{array}{c}\text { Rentang } \\
\text { Warna } \\
\text { Merah (a+) }\end{array}$ & $\begin{array}{c}\text { Rerata } \\
(\boldsymbol{\%})\end{array}$ \\
\hline P1 & 1 & 49,23 & $49,2 \mathrm{a}$ \\
& 2 & 49,17 & \\
P2 & 1 & 40,01 & $40,03 \mathrm{~b}$ \\
& 2 & 40,05 & \\
P3 & 1 & 34,22 & $34,25 \mathrm{c}$ \\
& 2 & 34,28 & \\
\hline
\end{tabular}

Keterangan: huruf yang sama di belakang angka pada kolom yang sama menunjukkan tidak berbeda nyata $(\mathrm{p}>0.05)$

Tabel 7. Rerata Rentang Warna Kuning Jus Kecambah Kedelai dan Wortel

\begin{tabular}{cccc}
\hline Sampel & Ulangan & $\begin{array}{c}\text { Rentang } \\
\text { Warna } \\
\text { Kuning (b+) }\end{array}$ & $\begin{array}{c}\text { Rerata } \\
(\%)\end{array}$ \\
\hline P1 & 1 & 38,73 & $38,77 \mathrm{a}$ \\
& 2 & 38,81 & \\
P2 & 1 & 43,11 & $43,15 \mathrm{~b}$ \\
& 2 & 43,19 & \\
P3 & 1 & 49,09 & $49,295 \mathrm{c}$ \\
& 2 & 49,05 & \\
\hline
\end{tabular}

Keterangan: huruf yang sama di belakang angka pada kolom yang sama menunjukkan tidak berbeda nyata $(p>0.05)$ 
dengan jus kecambah kedelai dan wortel dengan blanching 5 menit. Jus kecambah kedelai dan wortel tanpa blanching berbeda dengan jus kecambah kedelai dan wortel dengan blanching 10 menit. Selanjutnya, jus kecambah kedelai dan wortel dengan blanching 5 menit berbeda dengan jus kecambah kedelai dan wortel dengan blanching 10 menit. Uji warna jus kecambah kedelai dan wortel meliputi warna merah pada Tabel 6, warna kuning pada Tabel 7 dan kecerahan dapat dilihat pada Tabel 8.

Tabel 8. Rerata Tingkat Kecerahan Jus Kecambah Kedelai dan Wortel

\begin{tabular}{cccc}
\hline Sampel & Ulangan & $\begin{array}{c}\text { Tingkat } \\
\text { Kecerahan } \\
(\mathbf{L})\end{array}$ & $\begin{array}{c}\text { Rerata } \\
(\boldsymbol{\%})\end{array}$ \\
\hline P1 & 1 & 43,28 & $43,29 \mathrm{a}$ \\
& 2 & 43,31 & \\
P2 & 1 & 51,09 & $51,10 \mathrm{~b}$ \\
& 2 & 51,11 & \\
P3 & 1 & 57,42 & $57,45 \mathrm{c}$ \\
& 2 & 57,49 & \\
\hline
\end{tabular}

Keterangan: huruf yang sama di belakang angka pada kolom yang sama menunjukkan tidak berbeda nyata $(\mathrm{p}>0.05)$

Jus kecambah kedelai dan wortel tanpa blanching berbeda dengan jus kecambah kedelai dan wortel dengan blanching 5 menit. Jus kecambah kedelai dan wortel tanpa blanching berbeda dengan jus kecambah kedelai dan wortel dengan blanching 10 menit. Selanjutnya, jus kecambah kedelai dan wortel dengan blanching 5 menit berbeda dengan jus kecambah kedelai dan wortel dengan blanching 10 menit.

Jus kecambah kedelai dan wortel tanpa blanching berbeda dengan jus kecambah kedelai dan wortel dengan blanching 5 menit.Jus kecambah kedelai dan wortel tanpa blanching berbeda dengan jus kecambah kedelai dan wortel dengan blanching 10 menit. Selanjutnya, jus kecambah kedelai dan wortel dengan blanching 5 menit berbeda dengan jus kecambah kedelai dan wortel dengan blanching 10 menit.

Tingkat kecerahan jus kecambah kedelai dan wortel tanpa blanching berbeda dengan jus kecambah kedelai dan wortel dengan blanching 5 menit. Jus kecambah kedelai dan wortel tanpa blanching berbeda dengan jus kecambah kedelai dan wortel dengan blanching 10 menit. Selanjutnya, jus kecambah kedelai dan wortel dengan blanching 5 menit berbeda dengan jus kecambah kedelai dan wortel dengan blanching 10 menit.

Hasil rerata skor uji hedonik aroma jus kecambah kedelai dan wortel dapat dilihat pada Gambar 1.

Aroma jus kecambah kedelai dan wortel tanpa blanching berbeda dengan

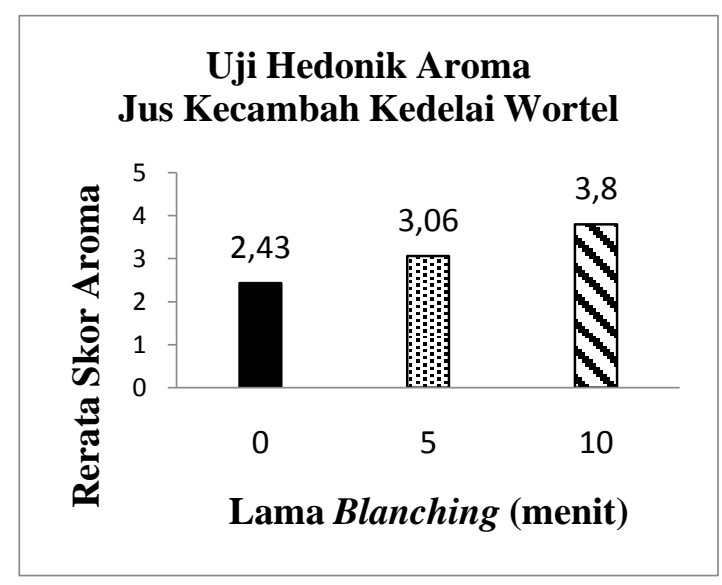

Gambar 1. Uji Hedonik Aroma Jus Kecambah Kedelai Wortel

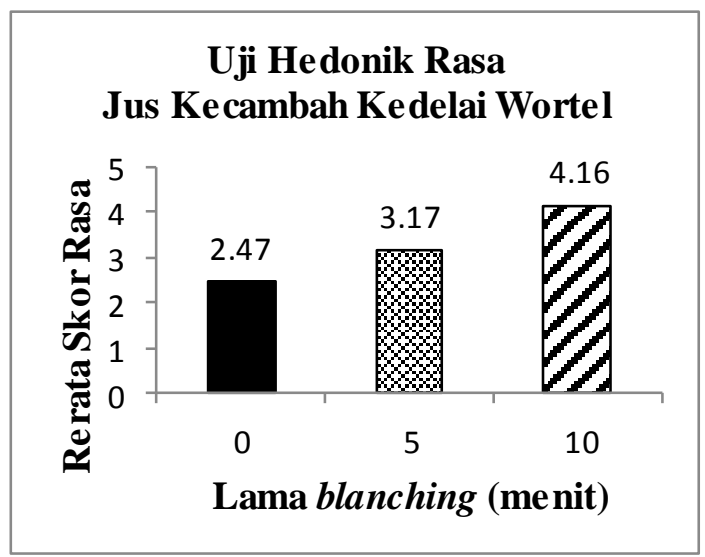

Gambar 2. Uji Hedonik Rasa Jus Kecambah Kedelai Wortel 
jus kecambah kedelai dan wortel dengan blanching 5 menit. Jus kecambah kedelai dan wortel tanpa blanching berbeda dengan jus kecambah kedelai dan wortel dengan blanching 10 menit. Selanjutnya, jus kecambah kedelai dan wortel dengan blanching 5 menit berbeda dengan jus kecambah kedelai dan wortel dengan blanching 10 menit

Hasil rerata skor uji hedonik rasa jus Kecambah Kedelai dan Wortel dapat dilihat pada Gambar 2. Rasa jus kecambah kedelai dan wortel tanpa blanching berbeda dengan jus kecambah kedelai dan wortel dengan blanching 5 menit. Jus kecambah kedelai dan wortel tanpa blanching berbeda dengan jus kecambah kedelai dan wortel dengan blanching 10 menit.Selanjutnya, jus kecambah kedelai dan wortel dengan blanching 5 menit berbeda dengan jus kecambah kedelai dan wortel dengan blanching 10 menit.

Hasil rerata skor uji hedonik warna

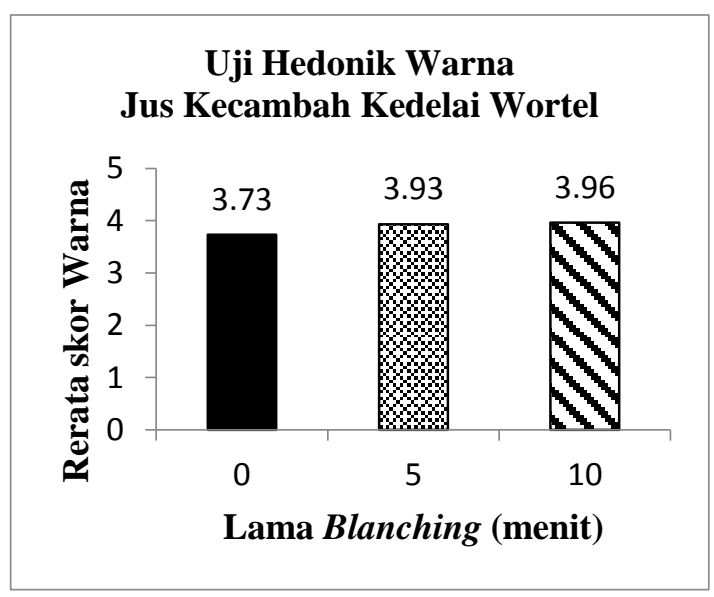

\section{Gambar 3. Uji Hedonik Warna Jus Kecambah Kedelai Wortel}

jus kecambah kedelai dan wortel dapat dilihat pada Gambar 3. Rerata uji hedonik terhadap warna masing-masing tidak memiliki perbedaan signifikan. Skor rerata warna setiap perlakuan sebanyak 3,73 (tanpa blanching), 39,3(blanching 5 menit) dan 3,96 (tanpa blanching 10 menit).

\section{PEMBAHASAN}

Nilai rerata kadar $\beta$-karoten jus kecambah kedelai dan wortel pada Tabel 1 menunjukkan bahwa peningkatan lama waktu blanching nyata menurunkan kadar $\beta$-karoten. Menurut Asgar (2006) kerusakan $\beta$-karoten dapat terjadi karena terdapat perubahan suhu. semakin tinggi suhu dan semakin lama waktu blanching, maka semakin menurun kandungan $\beta$-karoten dalam suatu bahan. Hal ini dikarenakan $\beta$-karoten bersifat tidak stabil jika berada pada suhu tinggi dengan lama waktu lebih panjang. Hal ini karena $\beta$ karoten yang mengikat protein larut dalam air dan blanching wortel untuk waktu yang lama akan melepaskan karoten dari karoten yang terikat protein ke dalam air.

Degradasi karotenoid dapat disebabkan oleh suhu dan lama waktu pemanasan. Menurut Mas'ud (2011), degradasi karotenoid terjadi lebih besar apabila suhu meningkat dibanding degradasi karotenoid apabila waktu pemanasan semakin lama. Hasil penelitian Sahidin et al dalam Mas'ud (2011) menunjukkan bahwa semakin tinggi suhu dan semakin lama pemanasan mengakibatkan degradasi $\beta$-karoten

Nilai reratakadar vitamin Ejus kecambah kedelai dan wortel pada Tabel 2 menunjukkan bahwa peningkatan lama waktu blanching nyata menurunkan kadar vitamin E. Hal ini dapat terjadi karena pada proses blanching merupakan proses pengolahan panas dengan adanya paparan oksigen. Tejasari (2005) menjelaskan bahwa vitamin E bersifat tidak stabil pada suhu kamar dengan adanya oksigen, asam, garam ferri dan sinar UV, mudah teroksidasi terutama jika ada oksigen dan suhu tinggi. Andarwulan dan Koswara (1992) menambahkan apabila keadaan tanpa oksigen, vitamin E stabil terhadap panas pada suhu diatas $200^{\circ} \mathrm{C}$. 
Penelitian yang dilakukan Pambudi, dkk. (2009) menjelaskan bahwa proses pemanasan mempunyai pengaruh signifikan terhadap kadar vitamin E sehingga proses pemanasan dapat menurunkan kadar vitamin E. Evansa, et. al. (2002) menambahkan bahwa kedelai yang dipaparkan di tempat terbuka dengan kontak ultraviolet dan oksigen akan berpengaruh pada hilangnya kandungan vitamin $\mathrm{E}$ khususnya tokoferol. Hal ini terutama disebabkan karena terjadi destruksi tokoferol oleh derivat asam lemak yang secara kimia aktif, yang terbentuk selama pemanasan dan oksidasi (Andarwulan, dkk. 2013)

Persentase kapasitas antioksidanjus kecambah kedelai dan wortel menunjukkan bahwa peningkatan lama waktu blanching nyata menurunkan kapasitas antioksidan. Hal ini dapat terjadi karena terjadi penurunan kadar vitamin pada bahan. Penurunan kadar vitamin pada bahan dapat disebabkan oleh perubahan su$\mathrm{hu}$, paparan oksidasi dan cara pengolahan. Penggunaan metode blanching dalam pembuatan jus ini dapat menjadi salah satu alasannya. Menurut Lean (2013), pada metode basah, nutrisi hilang dengan berbagai cara. Utamanya adalah proses melelehnya nutrisi larut air terutama vitamin dan unsur mineral kedalam air masak. Adanya kapasitas enzim pengoksidasi juga menyebabkan hilangnya nutrisi akibat keberadaan oksigen di dalam air dan udara panas.

Jus kecambah kedelai dan wortel berasal dari bahan makanan sumber vitamin E dan vitamin A. Walaupun kedua vitamin ini merupakan vitamin larut lemak, penurunan kadar vitamin dari masing-masing bahan masih dapat terjadi meski cara pengolahan dengan media air. Menurut Winarno (2007), vitamin A pada umumnya stabil pada keadaan panas, asam dan alkali. Namun mempunyai sifat yang sangat mudah teroksidasi oleh udara dan akan rusak bila dipanaskan pada suhu tinggi bersama udara, sinar, dan lemak yang sudah tengik. Lebih lanjut Mas'ud (2011), mengatakan bahwa kapasitas karotenoid akan menurun karena perubahan isomer trans menjadi bentuk cis.

Berbeda dengan kerusakan vitamin oleh suhu yang dapat dikendalikan, rusaknya vitamin oleh oksidasi cenderung susah dikendalikan. Menurut Muchtadi, dkk. (2013), beberapa bahan makanan cenderung mengikat oksigen dari udara, sedangkan oksigen adalah oksidan yang terdapat di sekeliling bahan pangan.

Persentase uji viskositas jus kecambah kedelai dan wortel pada Tabel 5 menunjukkan bahwa peningkatan lama waktu blanching nyata meningkatkan viskositas jus. Menurut Puspasari, dkk. (2009), pada saat perebusan terjadi proses penguapan dan terjadi pemekatan. Lebih lanjut Tejasari (2005), saat air menguap dan larutan menjadi pekat, kekentalan larutan akan meningkat dengan tajam.

Bahan yang terkandung di dalam jus berasal dari kecambah kedelai dan wortel. Menurut Astawan dan Kasih (2008), kecambah kedelai memiliki kandungan protein yang tinggi yaitu sekitar $9 \mathrm{~g} / 100 \mathrm{~g}$ bahan pangan. Koagulasi protein dapat terjadi akibat perlakuan pemanasan yang terjadi. Winarno (2007), menjelaskan bahwa koagulasi berawal dari pemanasan yang dapat menyebabkan pemutusan ikatan hidrogen yang menopang struktur sekunder dan tersier suatu protein sehingga menyebabkan sisi hidrofobik dari gugus samping polipeptida akan terbuka. Hal inilah yang menyebabkan kelarutan protein semakin turun.

Penelitian yang dilakukan oleh Asrif dan Malaka (2011) pengaruh lama pemanasan terhadap viskositas produk susu mengungkapkan bahwa perlakuan LTLT (low temperature low time) dimiringkan sehingga struktur koagulasi dapat terlihat dengan jelas akibat dari perlakuan panas selama 30 menit pada suhu $63^{\circ} \mathrm{C}$. Penda- 
pat yang sama diungkapkan Soeparno (1998) bahwa semakin lama waktu pemanasan dapat meningkatkan viskositas susu pada saat mendekati titik koagulasi protein susu. Lebih lanjut Phadungath (2005), mengatakan bahwa pengaruh panas terhadap viskositas susu tergantung pada temperatur pemanasan. Pemanasan air susu dengan suhu yang rendah mengakibatkan penurunan viskositas sedangkan pemanasan yang lama dapat menghasilkan peningkatan viskositas.

Keberadaan pektin sebagai agen pembentuk gel yang terkandung di dalam wortel dapat menjadi salah satu penyebab meningkatnya viskositas jus. Tuhuloula. (2013) menjelaskan kandungan pektin dapat ditemukan pada berbagai jenis buah dan sayur seperti, apel dan wortel. Nugraheni (2007) menambahkan, pektin dapat larut dalam air terutama air panas dan apabila dalam larutan koloid menyebabkan terjadinya kekentalan.

Pengujian terhadap warna dilakukan dengan alat spektofotometer yang dibaca adalah $L^{*}, a^{*}, b^{*}$. Nilai $L^{*}$ menyatakan parameter kecerahan ang mempunyai nilai dari 0 (hitam ) hingga 100 (putih). Nilai a* menyatakan cahaya pantulan campuran merah hijau dengan nilai a+ (positf) dari 0-100 untuk warna merah dan nilai -a(negatif) dari 0-(-80) untuk warna hijau. Nilai $b^{*}$ menyatakan campuran warna biru kuning dengan nilai $b$ +(positif) dari 0-70 untuk kuning dan nilai -b (negatif) dari 0-(-70) untuk warna biru (Budjianto, 2010)

Hasil analisis warna terhadap jus kecambah kedelai dan wortel meliputi 3 parameter yaitu L* (kecerahan), a* (merah), $\mathrm{b}^{*}$ (kuning). Rerata warna $\mathrm{L}^{*}$ paling tinggi $(57,45)$ pada jus dengan lama blanching 10 menit yang berarti warna mengarah ke putih atau memudar dibandingkan dengan jus dengan lama blanching 5 menit dan tanpa blanching. Rerata warna merah (a*) paling tinggi, $(49,02)$ pada jus tanpa blanching dan rerata warna kuning (b*) paling tinggi, $(57,45)$ pada jus dengan lama blanching 10 menit. Warna jingga pada jus dengan perlakuan tanpa blanching, 5 menit blanching, hingga ke 5 menit blanching berangsur-angsur memudar kearah warna kuning.

Warna jingga kekuningan mendominasi pada produk ini Hal ini disebabkan oleh warna pigmen karotenoid yang banyak terkandung dalam wortel. Warna jingga ke kuning selama perebusan terjadi akibat pigmen karotenoid yang dapat menyebabkan memudarnya warna buah dan sayur (Andarwulan, dkk. 2013). Warna $\beta$-karoten akibat reaksi isomerisasi cis-trans oksidasi membentuk epoxy karotenoid dan apokarotenal (Klaui, H dan Bauernfeind, J.C. 1981)

de Man dalam Puspasari (2011), menambahkan oksidasi merupakan salah satu reaksi yang paling signifikan menyebabkan kerusakan $\beta$-karoten, sehingga warna memudar. Oksidasi pada jus kecambah kedelai wortel terjadi ketika blanching dilakukan tanpa tutup yang menyebabkan kontak langsung bahan dengan oksigen bebas di udara

Data analisis uji hedonik lama waktu blanching mempengaruhi tingkat kesukaan panelis terhadap aroma jus kecambah kedelai wortel. Nilai rerata tertinggi dihasilkan oleh perlakuan lama blanching 10 menit $(3,80)$ dan nilai terendah dengan perlakuan tanpa blanching $(2,43)$.

Aroma khas kecambah kedelai dan wortel yang langu menyebabkan panelis lebih menyukai jus dengan perlakuan blanching. Hal ini disebabkan karena blanching merupakan salah satu teknik pemanasan yang dapat memperbaiki aroma yang tidak diinginkan. Blanching yang dilakukan tanpa tutup memberikan efek hilangnya aroma khas langu dari kedua bahan tersebut. Penguapan yang terjadi pada pemanasan menyebabkan aroma spesifik bahan sulit dipertahankan (Puspasari, dkk. 2009) 
Data analisis uji hedonik lama waktu blanching mempengaruhi tingkat kesukaan panelis terhadap rasa jus kecambah kedelai wortel. Nilai rerata tertinggi dihasilkan oleh perlakuan lama blanching 10 menit dan nilai terendah dengan perlakuan tanpa blanching.

Berdasarkan data uji hedonik, panelis lebih menyukai rasa pada jus kecambah kedelai wortel dengan perlakuan 10 menit blanching. Hal ini dikarenakan rasa langu yang dibawa oleh kedua bahan utama yaitu kecambah kedelai dan wortel sudah cukup tersamarkan. Menurut Muchtadi (2013), blanching bertujuan untuk meginaktifkan enzim yang tidak diinginkan yang mungkin dapat merubah warna, tekstur, citarasa, maupun nilai nutrisinya.

Jus dengan perlakuan 10 menit blanching memiliki rasa kuat seperti susu kedelai pada umumnya sehingga dapat diterima dan disukai sebagian besar panelis. Proses pemanasan seperti perebusan, pengukusan, atau penyangraian merupakan satu rangkaian yang penting. Akibat dari proses pemanasan ini maka antitrypsin dan enzim lipoksigenase menjadi tidak aktif dan mengurangi bau langu (Evansa, et. al. 2002)

Data analisis uji hedonik lama waktu blanching tidak mempengaruhi tingkat kesukaan panelis terhadap warna jus kecambah kedelai wortel secara signifikan. Pembentukan warna pada jus kecambah kedelai wortel di pengaruhi oleh kandungan $\beta$-karoten. Astawan dan Kasih (2008), mengungkapkan $\beta$-karoten merupakan komponen paling penting dalam makanan yang berwarna jingga. Pemudaran warna jingga kearah kuning yang bertahap terjadi pada peningkatan lama waktu blanching dapat disebabkan oleh oksidasi $\beta$-karoten. Perlakuan tanpa tutup saat blanching menyebabkan kontak langsung dengan oksigen di udara, sehingga terjadi oksidasi (Puspasari, dkk. 2009).

\section{SIMPULAN DAN SARAN}

Berdasarkan hasil penelitian dan pembahasan yang telah dipaparkan, maka dapat ditarik kesimpulan sebagai berikut:

Lama blanching berpengaruh signifikan terhadap kadar $\beta$-karoten jus dan vitamin E jus . Semakin meningkat waktu blanching maka semakin menurun kadar $\beta$-karoten dan kadar vitamin $\mathrm{E}$ pada jus kecambah kedelai dan wortel. Lama blanching berpengaruh signifikan terhadap kapasitas antioksidan jus kecambah wortel. Semakin meningkat waktu blanching maka semakin menurun kapasitas antioksidan pada jus kecambah kedelai dan wortel. Lama blanching juga berpengaruh signifikan terhadap viskositas jus. Semakin meningkat waktu blanching maka semakin meningkat viskositas jus kecambah kedelai dan wortel. Viskositas tertinggi dimiliki oleh jus dengan lama blanching 10 menit sebesar $19,71 \mathrm{cps}$.

Terhadap tingkat kecerahan, lama blanching berpengaruh signifikan tingkat kecerahan dan warna jingga jus. Lama blanching berpengaruh signifikan terhadap tingkat kesukaan terhadap aroma dan rasa, namun tidak berbeda signifikan pada tingkat kesukaan terhadap warna.

\section{DAFTAR RUJUKAN}

Aisyah, Y., Rasdiansyah, \& Muhaimin. 2014. Pengaruh Pemanasan terhadap Aktivitas Antioksidan pada Beberapa Jenis Sayuran. Jurnal Teknologi dan Industri Pertanian Indonesia, 6(2): 05, (Online), (www. google. co.id, diakses 15 Juni 2015).

Asgar, A. \& Musaddad. 2006. Optimalisasi Cara, Suhu, dan Lama Blansing sebelum Pengeringan pada Wortel. Jurnal Hortikultura, 16(3): 245--252, (Online), (hortikultura. litbang.pertanian.go.id/jurnal_pdf/1 
63/Asgar_wortel.pdf, diakses $01 \mathrm{Mei}$ 2015).

Asrif \& Malaka, R. 2013. Pengaruh Susu Pasteurisasi terhadap Proses Gelatinasi Susu dengan Penambahan Buah Markisa (Passiflora edulis sims). (Online), (http://ratmawati-fapetunhs.blogspot.co.id, diakses 05 April 2016).

Andarwulan, N. \& Koswara, S. 1992. Kimia Vitamin. Jakarta: Rajawali Pers.

Andarwulan, N., Kusnandar, F. \& Herawati, D. 2011. Analisis Pangan. Jakata: Dian Rakyat.

Astawan, M. \& Kasih, L. 2008. Khasiat Warna-warni Makanan. Jakarta: PT Gedia.

Gunawan, D. 2010. Serba-serbi Kecambah/Tauge. (Online), (www.Otbrando.blog.com/2010/01/artikel-serbaserbi-kecambah/tauge), diakses 12 Oktober 2015).

Hawusiwa, 2010. Blanching dan Pasteurisasi, (Online), (http://hawusiwa. blogspot.co.id/2010/03/blansingdan-pasteurisasi.html, diakses 12 Mei 2015).

Heltty. 2008. Terapi Jus Kacang Hijau untuk Penderita Kanker, (Online), (www.eprints.lib.ui.ac.id/445916/12 7172-tesis0458HeLNO8p-pengaruh jus-literatur.pdf, diakses 11 Februari 2015).

Joseph, J.A. 2002. Diet Sehat dengan Kode Warna Makanan. Terjemahan Lovely. Jakarta: Mizan Publika.

Klaui, H. \& Bauernfeind, J.C. 1981. Carotenoids as Food Colors. Di dalam Carotenoids as Colorants and Vitamin A Precursors. Bauernfeind, J.C. (ed.) New York: Academic Press.

Kumalaningsih, S. 2006. Antioksidan Alami Penangkal Radikal Bebas (Sumber, Manfaat, Cara Penyediaan dan Pengolahan). Surabaya: Trubus Agrisarana.
Kuntarsih, 2010. Konsumsi Masyarakat Indonesia di Bawah Rekomendasi WHO. (Online). (http://www. Republika.co.id/berita/breakingnews/nasi onal/10/06/14/119729 konsumsi-sayuran-rakyat-indonesia-masihrendah, diakses 3 Januari 2015).

Lean, M.E.J. 2013. Ilmu Pangan, Gizi \& Kesehatan Edisi ke-7. Terjemahan Nata Nilamsari \& Astri Fajriah. Yogyakarta: Pustaka Pelajar.

Lim, P. \& Lee, Y. 2004. Terapi Kanker (101 Resep Mencegah, Merawat, Menyembuhkan Kanker). Terjemahan: Rianto Slamet. Jakarta: Prestasi Pustaka Publisher.

Mas'ud, F. 2011. Optimasi Proses Pemanasan pada Pembuatan Chips Wortel Kaya Karotenoid Menggunakan Renponse Surface Methodology. Jurnal Agri Techno, 4(1): 1--10

Muchtadi \& Tien. 2013. Prinsip Proses dan Teknologi Pangan. Alfabeta: Bandung.

Nugraheni, M. 2007. Pengaruh Ekstrak Kecambah Kacang Hijau sebagai Sumber Nitrogen pada Pemanfaatan Limbah Tahu terhadap Karakteristik Nata De Soya Mentah dan Limbahnya. Jurnal Teknologi dan Kejuruan, 30(20): 185--195 (Online), (taff. uny.ac.id/sites/...nugraheni.../natadan-kesehatan-makalah-semnas20122.pdf, diakses 05 Juni 2016).

Phadungath, C. 2005. Casein Micelle Structure: A Concise Review. Songklanakarin Journal of Science and Technology, 27: 201--212

Poedjiadi, A. \& Supriyanti, F.M.T. 1994. Dasar-dasar Biokimia, Cetakan 2006. Jakarta: Unversitas Indonesia Press.

Puspasari, W. 2009. Pengaruh Penutupan dan Suhu pada Proses Perebusan terhadap Karakteristik Siru Wortel (Daucus carota L. Agrotekno, 15(1): 25--29, (Online), (www.Google. com, diakses 14 April 2016). 
Silalahi, J. 2006. Makanan Fungsional. Kanisius: Yogyakarta.

Soeparno. 1998. Ilmu dan Teknologi Susu. Yogyakarta: Universitas Gadjah Mada.

Tejasari. 2005. Nilai-Nilai Gizi Pangan. Yogyakarta: Graha Ilmu.
Tuhuloula. 2013. Karakteristik Pektin dengan Memanfaatkan Limbah Kulit Pisang dengan Metode Ekstraksi, Jurnal Konversi, 2(1): 21--27, (Online), (ppjp.unlam.ac.id).

Winarno, F.G. 2007. Teknobiologi Pangan. Jakarta: Gedia Gedia Pustaka Utama. 